This is an electronic reprint of the original article. This reprint may differ from the original in pagination and typographic detail.

Author(s): Tyrväinen, Pasi; Selin, Joona

Title: $\quad$ How to Sell SaaS: A Model for Main Factors of Marketing and Selling Software-as-aService

Year: $\quad 2011$

Version:

Please cite the original version:

Tyrväinen, P., \& Selin, J. (2011). How to Sell SaaS: A Model for Main Factors of Marketing and Selling Software-as-a-Service. In B. Regnell, I. van de Weerd, \& O. De Troye (Eds.), Software Business, Second International Conference, ICSOB 2011, Brussels, Belgium, June 8-10, 2011, Proceedings (pp. 2-16). Springer-Verlag. Lecture Notes in Business Information Processing, LNBIP, Vol 80, Part 2.

https://doi.org/10.1007/978-3-642-21544-5_2

All material supplied via JYX is protected by copyright and other intellectual property rights, and duplication or sale of all or part of any of the repository collections is not permitted, except that material may be duplicated by you for your research use or educational purposes in electronic or print form. You must obtain permission for any other use. Electronic or print copies may not be offered, whether for sale or otherwise to anyone who is not an authorised user. 


\title{
How to Sell SaaS: \\ A Model for Main Factors of Marketing and Selling Software-as-a-Service
}

\author{
Pasi Tyrväinen and Joona Selin \\ Department of Computer Science and Information Systems \\ Agora, P.O. Box 35 \\ FIN-40014 University of Jyväskylä, Finland \\ \{pasi.tyrvainen, joona.v.selin\}@jyu.fi
}

\begin{abstract}
Software-as-a-Service providers have been growing fast while the contemporary research literature has neglected analysis of their business-critical marketing and sales processes. In this paper we collect the key factors characterizing how to market and sell SaaS to business customers into an eight dimensional model. We also use an explorative multi-case study to observe six SaaS providers and validate the model. The interviewed providers emphasized use of the Internet for marketing communication while personal direct sale was the dominating sales approach. Customer acquisition cost was the key performance indicator for marketing and sales while customer lifetime value and churn were the KPIs in customer relationship management.
\end{abstract}

Keywords: Sales and marketing models, business models, software business, Software-as-a-Service, SaaS, key performance indicators, KPI.

\section{Introduction}

Youseff, Butrico ja Da Silva [1] defined Cloud computing as services used on demand through networks. They divide cloud services into five layers: cloud applications, cloud software environment, cloud infrastructure, software kernel and firmware/hardware. The most commonly known form of cloud applications is Software-as-a-Service (SaaS), where an application is used cross the network without installing it into the user device [2]. According to Gartner [3] the SaaS market will grow annually $17,7 \%$ till year 2013 . For software firms this will mean new business opportunities as well challenges in adapting to the new business environment.

A transition from a packaged software business provider to a SaaS provider following the best practices of the SaaS model will set new challenges to strategic management, but also to marketing and sales. So far the research literature has not addressed this problem while practitioners have published a volume of related material in the Web. Kaplan [4] and Mallya [5] have focused on the differences between marketing and selling traditional software and SaaS. An alternative approach emphasizes providing a solution to the customer rather than selling SaaS as such [6]. Domergue [7] focuses on providing value to the customer when selling SaaS. In

To appear in proceedings of ICSOB2011, The 2nd International Conference on Software Business. The original publication will be available at www.springerlink.com 
general, some of the previous studies emphasize ease of selling SaaS [8] while others speak about difficulty [9].

Our purpose is to initiate academic research on marketing and selling SaaS by presenting a model of the key factors for marketing and selling SaaS and related key performance indicators (KPI). In this paper we describe, how software products can be marketed and sold as services in business-to-business (B2B) markets according to the SaaS model. Later research can focus on the individual factors as well as to study the relationships between the factors. In section 2 of this paper we summarize shortly a literature review of the related background theories on marketing, software business and SaaS. In section 3 we construct the model for the main factors determining how a firm markets and sells a SaaS offering based on the literature. Empirical research in section 4 is used for exploring the field and for validating the model in a multi-case study of six companies selling SaaS. In the end, we present a revised mode adopting the changes implied by the empirical observations.

\section{Marketing and Sales in Software Business}

Kotler and Keller [10] define marketing as a function and process of the organization, which creates, communicates and delivers value to customers and maintains customer relationships by means profitable to the firm and interest groups. One of the functions included is selling aiming at completing the sales case [11]. At the same time, marketing tries to make sales unnecessary by providing self-selling products, which the customers are willing to buy [10].

The two main approaches to marketing are transactional marketing and relationship marketing. From the transactional marketing viewpoint the firm can compete with four Ps, product, price, place, and promotion [12]. According to the relationship marketing approach, marketing is an interactive process, which builds, maintains and develops relationships, which comply with the goals of the participants [13]. Kotler and Keller [10] present a holistic view, which integrates the transactional view under the tile integrated marketing with the relationship view, and in addition, internal marketing and performance marketing. The integrated marketing addresses questions related to products and services, delivery channels as well as communication. Relationship marketing includes customers, partners and delivery channel related questions. Internal marketing focuses on firm internal marketing between the marketing department, other department and top management. Performance marketing focuses on revenue, brand value and ethical and legal operating environment. In this study we focus on questions related to integrated marketing which will match the expected low transaction costs of SaaS offerings as well as relationship marketing.

Customers have traditionally been divided into consumers and businesses, out of which we focus only on businesses in this study. Each firm can create applicable means to divide target customers into market segments sharing similar needs [11]. Criteria used can include demographic factors, such as vertical industry[14], firm size and location. Also technologies and practices used, purchasing practices and firmspecific characteristics can be used for segmenting [10] as well as customer lifetime 
value [15]. Following Berger and Nasr [16] we define customer lifetime value as the surplus of long-term income from customer reduced by customer relationship maintenance costs. This can be used for identifying profitable relationships but also for evaluating potential future customer base [17].

Software business includes segments with rather different characteristics with respect to marketing and sales. Embedded software is usually developed for a single company either as professional services or in-house. IT firms providing professional services implement bespoken systems as well as deploy and tailor enterprise systems for the customer. In professional service business trust is important as the software to be delivered does not yet exist [18]. The number of customers is small while transaction costs and the revenue per customer are high [19], which require investing on customer relationship management [18]. Instead, standardized and packaged software products with relatively low prices are examples of offerings of Internetgeneration firms with strong brand marketing and marketing alliances [18]. The customer-base is large and the users are distant to the vendors [19]. For these software product firms the marketing costs are a major share of the budget [20].

The relevant marketing means for software service business include relationship management, seminars, fairs and other form related to personal communication, software product business relies more on advertising and direct sales while both use Internet as a marketing channel [19]. Personal selling, representatives and valueadded-resellers (VAR) are typical sales channels for software service business. A network of software service firms can also co-produce a service offering for customers in process of value co-creation following the service-dominant logic. Instead, software product businesses use more wholesale and resale organizations as well as Internet as a sales channel [19]. In the international markets software service firms cooperating closely with customers tend to use representatives in the market, whereas firms developing semi-standardized enterprise solutions prefer sales subsidiaries of their own and firms offering mass-market products to consumers tend to choose cooperative entry modes where local organizations possess deep knowledge about the target market [21].

Software-as-a-Service (SaaS) can be characterized as a standard software product operated by the SaaS provider, delivered using standard Internet protocols and consumed as on-demand services by the customers, typically using Web browsers as the user interface. For the purposes of the empirical study we combined following criteria for compliance with the SaaS model from multiple sources (including $[1][2][22][23])$ :

1. Software is used with a Web browser or other thin client making use of standard internet protocol.

2. A standardized software product is provided with no customization.

3. There is no need to install software to the customer site.

4. Deployment requires no major integration or installation.

5. Customers pay for use of the software rather than licenses.

6. The same multitenant installation is provided for several customers.

From the user viewpoint low entry cost and pay-as-you-go pricing make adoption and use of SaaS attractive. From customer's perspective SaaS can be seen as outsourcing IT back-end management activities to the provider. From SaaS vendor viewpoint SaaS can be viewed as a software delivery and deployment model. It can 
also be seen as a business model sharing characteristics with software product business with high number of customers and low transaction costs. From this perspective the multitenant software can be seen as a cost-efficient model to provide services to new, underserved market segments, such as small enterprises [22]. SaaS shares also some characteristics of software services business with a need to avoid churn and invest on customer relationship management to retain customers.

\section{Marketing and Sales Model for SaaS}

Based on the literature it seems that providing SaaS services is technically cost efficient, but controlling the marketing and sales costs will be a major challenge for profitability of SaaS providers. The main factors of marketing and selling SaaS collected from the literature have been collected to the model presented in Figure 1. The model consists of eight dimensions representing eight variables; service provider size, service and implementation model, customer size, market communication channel, sales channel, role of buyer, entry transaction size, and customer life-cycle value. Based on the literature we expect the categories in the middle of the diagram are likely to co-occur and the categories in the outer rings are likely to co-occur. For example, a small SaaS service provider would be more likely to provide self-services through the internet to end users with small entry cost while a large service provider is likely to provide added value services to large customers.

Provider size and customer size dimensions in this model are categorize based on firm headcount to micro (less than 10 persons), small (10-49), mid-size (50-249) and large enterprises. According to Moore [24] firm size has major impact to the markets it will operate. The target market of a provider is defined by the target customer group, which is strongly related to the offering of the provider [19]. Zoltners, Sinha and Lorimer [25] state further, that a firm has to be able to organize the sales according to the status of the market including appropriate resourcing and size of the sales organization.

Service and implementation model describes the product strategy of the firm and the role of services and implementation in the business model. It also reflects the share of sources of income in the business. The categories in this dimension are self service and professional services including deployment, integration, tailoring, as well as training and consulting (adopted from [26]).

Customer size dimension in this model reflects the group of target customers. The categories follow the categories of the providers. According to Choudhary [27] and Sääksjärvi et al. [28] the target customer groups of SaaS providers span the full range from small enterprises to large ones. The chosen target customer group will impact the product strategy [19], the channels of market communication [11] as well as the sales channels [22].

Market communication channel represent the means of a SaaS provider to deliver information about the service to the customer [19] providing the means to increase the sales [11]. The marketing and sales channel solutions are thus tightly interconnected. Software product companies have typically high costs for creating brand awareness and recognition due to aggressive advertising, promotion and relationship building 
activities [18]. Use of Internet has been emphasized as a means to replace these traditional channels for SaaS firms [29] potentially providing some relief to the costs.

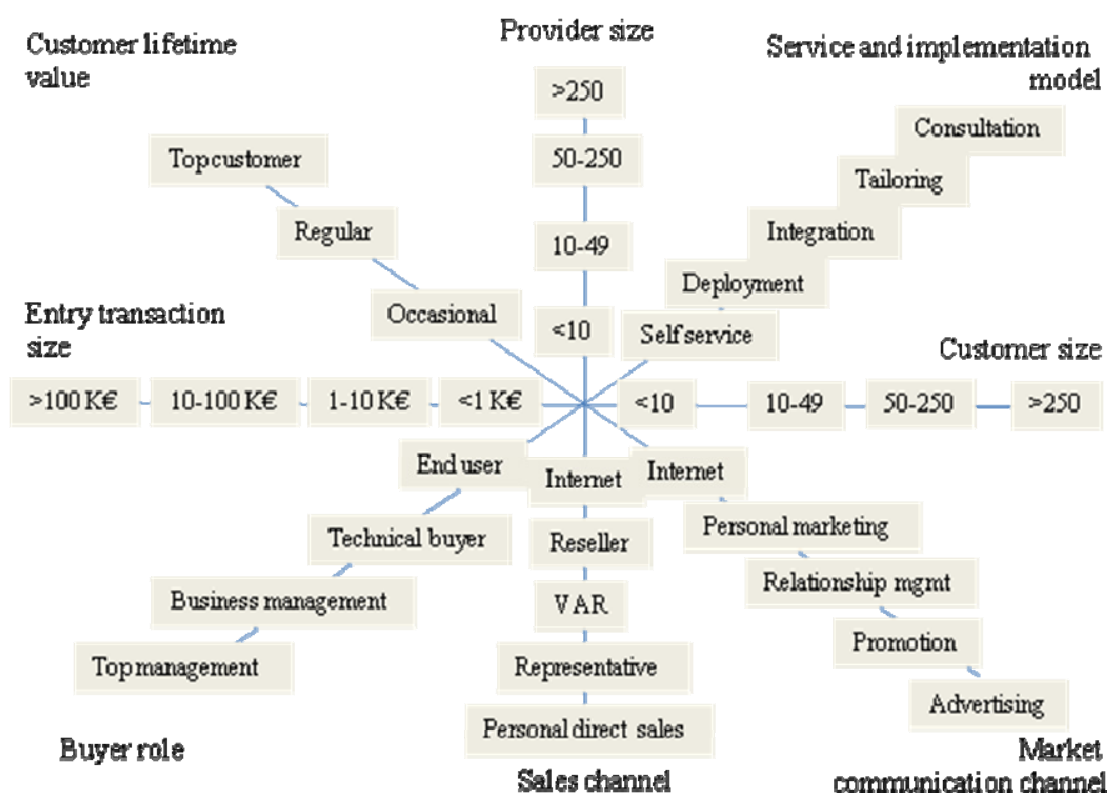

Fig. 1. The main factors of marketing and selling SaaS collected from the literature.

Sales channel dimension describes the sales solutions of a SaaS firm. That is, how the firm aims to complete the sales transactions. Chong and Carraro [22] mention use of Internet and direct personal sales as a sales channel for SaaS while Weobong [30] adds resellers, VAR and other channel partners, which are here referred to as "representatives".

Role of buyer of SaaS is shifting from technical buyers to business directors [31]. Moore [32] divides roles of buyers into top management, business management, technical buyers, and end users. He further states that the role of buyer shifts according to the life cycle of the product.

Entry transaction size will have major impact to adoption of SaaS in many cases. On one hand, the low cost of first transaction compared to traditional software licenses has commonly been referred as one of the customer benefits of SaaS [33]. On the other, the mismatch of cash flows is one of the challenges of SaaS providers [34]. By this Gardner refers to a situation, where the sales and marketing costs materialize at the sales event while the income realizes monthly during the contract period.

Customer lifetime value dimension represents two roles in this model. It can be used for value of existing and potential customer relationships. The costs of marketing communication and sales allocated to the new customers will have major impact to the lifetime value of a customer. Thus the transaction costs will set constraints to 
marketing communications and sales. [16] The categories for this dimension are based on the categories of Tähtinen and Parvinen [19].

\section{Multi-Case Study}

The primary goals of this empirical work are to explore the target domain, which has not been researched earlier as well as to evaluate the marketing and sales model for SaaS constructed based on the literature. We first describe the methodology chosen, next, present the results, and finally, analyze the model. Based on the analysis we present an updated model adopting the changes implied by this empirical part.

\subsection{Research Process and Methods}

Due to explorative nature of the research we chose multi-case study as the research method. Case study match well with research of processes and provides detailed and intensive data from small set of relate cases [35]. We chose thematic interviews as the main data collection method due to the new and unexplored nature of the topic. This enables also refining the questions and answers if needed. Validity of interview data can be verified from complementary data sources and interviews can be used for exploring relationships of phenomena and for creation of new hypothesis [36]. Complementary data was collected from the Web pages and annual statements of the interviewed companies to verify and complement the interview data.

The target group of interviewees was sales and marketing managers representing SaaS providers in Finland. Within this target group we aimed at finding as heterogeneous set of firms as possible to include firms with a variety of SaaS business models. We used the National Software Industry Survey [23] and Web pages of the Cloud Software Program [37] as sources of potential SaaS providers. With the resources available, we chose seven firms providing SaaS in B2B markets. We determined the managers representing the firms after approaching them by email followed by a phone call. One of the firms did not answer to our contacts, thus the final set of interviewees included persons from six firms. The roles of the six interviewees include $\mathrm{CEO}$, service manager, sales director, product manager and executive advisor. All the interviewees had the deep understanding of SaaS business needed for carrying out the interviews.

We sent an introductory letter to the interviewees with a 1,5 pages questioner annex prior to the interviews to give the persons a chance to get familiar with the questions. The questioner annex contained a listing of the topic areas and 3-5 interview questions under each topic area. The topic areas were formed from the dimensions of the model and the required background data: background information of the interviewed firm and person (summarized in Table 1), SaaS offering (compliance with the SaaS criteria in section 2, implementation and delivery model, networks), customers, sales process, marketing communication, sales financials, customer lifetime value, and summary questions.

We tested the use of the interview questions in a pre-interview and on this basis implemented minor modifications to improve the fluency of the later interviews. 
These changes have no major impact to the results and thus the results of the preinterview are included in the results. All the interviews took place during AugustSeptember 2010, four in firm premises, two were conducted by phone. The average duration of the interviews was 1 hour and 11 minutes. The interviews were digitally recorded. Chosen segments of the recordings were transcript to written documents on the first pass and verified on the second pass soon after the interviews. The written documents were sent for interviewees for comments, corrections and additions. The collected data was classified thematically based on the model presented in Figure 1.

\subsection{Characteristics of the Case Firms}

Table 1 presents characteristics of the firms whose representatives we interviewed. The headcount figures represent the number of employees in Finland. Number of years the firm has conducted SaaS business is reflected in their business model. Firms $\mathrm{A}, \mathrm{B}$, and $\mathrm{C}$ have conducted SaaS business since they were established while firms D, $\mathrm{E}$, and $\mathrm{F}$ have started providing SaaS later on. The annual revenue 2009 refers to the total business revenue including both SaaS and other business. SaaS revenue share includes revenue from SaaS service fees and related added value services for five firms. This share was not recorded and could not be estimated by firm D. Similarly, firm B did not disclose profitability data, but is still in early phase, like firm A. Compliance with SaaS model is estimated based on the criteria presented earlier.

Table 1. Firm characteristics and background information of the firms.

\begin{tabular}{|c|c|c|c|c|c|c|}
\hline Firms & Firm A & Firm B & Firm C & Firm D & Firm E & Firm F \\
\hline Business model & $\begin{array}{l}\text { ASP / } \\
\text { SaaS }\end{array}$ & SaaS & SaaS & $\begin{array}{l}\text { Profession } \\
\text { al SW } \\
\text { services }\end{array}$ & $\begin{array}{l}\text { Profession } \\
\text { al SW } \\
\text { services }\end{array}$ & $\begin{array}{l}\text { Software } \\
\text { product }\end{array}$ \\
\hline Interviewee role & $\begin{array}{l}\text { Managing } \\
\text { Director }\end{array}$ & $\begin{array}{l}\text { Sales } \\
\text { Director }\end{array}$ & $\begin{array}{l}\text { Managing } \\
\text { Director }\end{array}$ & $\begin{array}{l}\text { Executive } \\
\text { Advisor }\end{array}$ & $\begin{array}{l}\text { Service } \\
\text { Director }\end{array}$ & $\begin{array}{l}\text { Product } \\
\text { Manager }\end{array}$ \\
\hline $\begin{array}{l}\text { Headcount / } \\
\text { in sales }\end{array}$ & $\begin{array}{l}<10 \\
20 \%\end{array}$ & $\begin{array}{l}<10 \\
25 \%\end{array}$ & $\begin{array}{l}10-49 \\
52 \%\end{array}$ & $\begin{array}{l}>250 \\
3,5 \%\end{array}$ & $\begin{array}{l}50-250 \\
7,5 \%\end{array}$ & $>250$ \\
\hline $\begin{array}{l}\text { Years in } \\
\text { SaaS business }\end{array}$ & 2 & 1 & 11 & 5 & 1 & 3 \\
\hline $\begin{array}{l}\text { Revenue } 2009 \\
\text { (change from prev) }\end{array}$ & $\begin{array}{l}<1 \mathrm{M} € \\
(+40 \%)\end{array}$ & $\begin{array}{l}<1 \mathrm{M} € \\
(\mathrm{~N} / \mathrm{A})\end{array}$ & $\begin{array}{l}1-10 \mathrm{M} € \\
(+7 \%)\end{array}$ & $\begin{array}{l}>1000 \mathrm{M} € \\
(-9 \%)\end{array}$ & $\begin{array}{l}11-100 \mathrm{M} € \\
(\mathrm{~N} / \mathrm{A})\end{array}$ & $\begin{array}{l}101- \\
1000 \mathrm{M} € \\
(+11 \%)\end{array}$ \\
\hline $\begin{array}{l}\text { SaaS share from } \\
\text { revenue }\end{array}$ & $93 \%$ & $100 \%$ & $100 \%$ & na. & $15 \%$ & $50 \%$ \\
\hline $\begin{array}{l}\text { Profit } 2009 \\
\text { (change from prev) }\end{array}$ & $\begin{array}{l}-90 \% \\
\text { (na.) }\end{array}$ & na. & $\begin{array}{l}21 \% \\
(+19 \%)\end{array}$ & $\begin{array}{l}12 \% \\
(-2 \%)\end{array}$ & $\begin{array}{l}13 \% \\
\text { (na.) }\end{array}$ & $\begin{array}{l}23 \% \\
(-1 \%)\end{array}$ \\
\hline $\begin{array}{l}\text { Compliance with } \\
\text { SaaS definition }\end{array}$ & $3 / 6$ & $6 / 6$ & $6 / 6$ & $4 / 6$ & $6 / 6$ & $5 / 6$ \\
\hline $\begin{array}{l}\text { Marketing \& sales } \\
\text { cost per revenue }\end{array}$ & $50 \%$ & $40 \%$ & $60 \%$ & na. & na. & $41 \%$ \\
\hline
\end{tabular}




\subsection{Detailed Results}

This sub-section presents the results organized according to the factors impacting marketing and selling SaaS presented in the model in section 3. Table 2 summarizes the results representing the factors and their values in rows. Each column from A to $\mathrm{F}$ represents the results of one firm.

The first set of rows represents the alternative components of service and implementation models. Half of the firms - A, B and F - deliver SaaS as self-service while others provide some level of deployment, training and other services. Firm D has positioned itself as a provider of high added value services. Firm E embeds the SaaS offering in a bundle provided for a single fee, but not as a self-service package.

"We do not want to consult ourselves, we want our partners to do it." Sales Director, Firm B.

The second set of rows describes service and implementation model of the interviewed SaaS providers by presenting the split of revenue between SaaS fees and professional services. The use of self-service is visible as a high share of revenue from SaaS in Firms B, C and F. Firm D did not provide an estimate share of the share of SaaS fees from the total revenue. The content of professional services provided varies according to the firm. Firm A provides specification, deployment and consulting services and these form $75 \%$ of their revenue. Firm B gets only $5 \%$ from services containing mainly training. Firm $\mathrm{C}$ divides services into training, deployment projects and after sales support. There are also differences between the firms in using external resources. Firms D and F do not use partners for service creation while A, B and $\mathrm{C}$ use technology partners for providing hosting services and platforms for providing SaaS services. Firms B and E use also external R\&D resources.

Customer and provider sizes are represented in the same set of rows with " $\mathrm{C}$ " denoting size of the Customer organizations in the main customer groups and "P" denoting Provider size. The sizes of customer follow nicely the provider sizes. The small SaaS Firms A and B targeted small customers with less than 50 employees while the larger providers have targeted mid size and large customers. For Firm $\mathrm{F}$ the size of customer is less relevant while for others it pays an important role.

"In this kind of services the main common factor in firm purchase behavior is the number of employees." - CEO, Firm C.

The buyer in small firms is usually a top management. In medium and large companies the business managers buy SaaS services matching their needs and departmental budgets.

"Business is more interested in SaaS... customer's IT organization feels threatened by new solutions. " - Executive advisor, Firm D.

The next set of rows is the market communication channels of the interviewed SaaS providers. In addition to traditional marketing means all the interviewees used Internet for marketing their SaaS offering, e.g. using Web pages, targeted e-mail campaigns, newsletters, search marketing, viral campaigns, banners etc.

"We have tried to live in the world, that when purchases are made in the Web then also visibility will be in the Web." - Sales director, Firm B. 
Table 2. Summary of the interview results. Each column with title from A to F represents a firm. A set of rows represents alternative categories in one dimension of the model. " $X$ " denotes that this category applies to the firm. Customer and provider sizes are represented in the same rows with "P" denoting Provider. There are also two sets of rows for service and implementation modes, and customer lifetime value is excluded from this table.

\begin{tabular}{|c|c|c|c|c|c|c|}
\hline Firms & $\bar{A}$ & $\mathrm{~B}$ & $\mathrm{C}$ & $\bar{D}$ & $\bar{E}$ & $\mathrm{~F}$ \\
\hline \multicolumn{7}{|l|}{ Service components } \\
\hline Self service & $\mathrm{X}$ & $\mathrm{X}$ & $\mathrm{X}$ & & & $\mathrm{X}$ \\
\hline Deployment service & $\mathrm{X}$ & & & $\mathrm{X}$ & $\mathrm{X}$ & \\
\hline Integration & & & & $\mathrm{X}$ & $\mathrm{X}$ & \\
\hline Tailoring & $\mathrm{X}$ & & & $\mathrm{X}$ & & \\
\hline Training and consulting & $\mathrm{X}$ & & & $\mathrm{X}$ & $\mathrm{X}$ & \\
\hline \multicolumn{7}{|l|}{ Revenue split } \\
\hline SaaS fees $(\%)$ & $25 \%$ & $95 \%$ & $87 \%$ & na. & $80 \%$ & $98 \%$ \\
\hline Professional services (\%) & $75 \%$ & $5 \%$ & $13 \%$ & na. & $20 \%$ & $2 \%$ \\
\hline \multicolumn{7}{|c|}{ Customer and Provider sizes } \\
\hline$<10$ & $\mathrm{CP}$ & $\mathrm{P}$ & & & & $\mathrm{C}$ \\
\hline $10-49$ & $\mathrm{C}$ & $\mathrm{C}$ & $\mathrm{P}$ & & & $\mathrm{C}$ \\
\hline $50-250$ & & & $\mathrm{C}$ & $\mathrm{C}$ & $\mathrm{CP}$ & $\mathrm{C}$ \\
\hline$>250$ & & & & $\mathrm{CP}$ & $\mathrm{C}$ & $\mathrm{CP}$ \\
\hline \multicolumn{7}{|l|}{ Buyer roles } \\
\hline \multicolumn{7}{|l|}{ End user } \\
\hline Technical buyer & & & & $X$ & & \\
\hline Business management & & & $\mathrm{X}$ & $\mathrm{X}$ & $\mathrm{X}$ & \\
\hline Top management & $\mathrm{X}$ & $\mathrm{X}$ & & & & \\
\hline \multicolumn{7}{|l|}{ Market communication } \\
\hline Internet & $\mathrm{X}$ & $\mathrm{X}$ & $\mathrm{X}$ & $\mathrm{X}$ & $\mathrm{X}$ & $\mathrm{X}$ \\
\hline Personal marketing & $\mathrm{X}$ & & $\mathrm{X}$ & $\mathrm{X}$ & $\mathrm{X}$ & $\mathrm{X}$ \\
\hline Relationships & $\mathrm{X}$ & $\mathrm{X}$ & $\mathrm{X}$ & & & $\mathrm{X}$ \\
\hline Promotion & & & $\mathrm{X}$ & $\mathrm{X}$ & $X$ & $\mathrm{X}$ \\
\hline \multicolumn{7}{|l|}{ Advertising } \\
\hline \multicolumn{7}{|l|}{ Sales channels } \\
\hline Internet & & $\mathrm{X}$ & & & & \\
\hline Reseller & & & & & & $\mathrm{X}$ \\
\hline VAR & $\mathrm{X}$ & $\mathrm{X}$ & $\mathrm{X}$ & & & $\mathrm{X}$ \\
\hline \multicolumn{7}{|l|}{ Representative } \\
\hline Personal selling & $\mathrm{X}$ & $\mathrm{X}$ & $\mathrm{X}$ & $\mathrm{X}$ & $\mathrm{X}$ & $\mathrm{X}$ \\
\hline \multicolumn{7}{|l|}{ Entry transaction size } \\
\hline$<1 \mathrm{~K} €$ & & & & & & $\mathrm{X}$ \\
\hline $1-10 \mathrm{~K} €$ & $\mathrm{X}$ & $\mathrm{X}$ & $\mathrm{X}$ & $\mathrm{X}$ & & \\
\hline $10-100 \mathrm{~K} €$ & & & & & $\mathrm{X}$ & \\
\hline$>100 \mathrm{~K} €$ & & & & & & \\
\hline
\end{tabular}


The rows representing sales channels of the interviewed SaaS providers follow the rows representing the marketing channels. All the interviewed firms use personal selling and for Firms D and E this is the only sales channel. Other four firm use also value added resellers. Firm $\mathrm{F}$ used early Internet sales but gave up and uses now strongly resellers. Firm B is the only one using Internet as a sales channel, although self-service was the only service and implementation model for Firms B, C and F.

"The market is not mature enough for self-service [through the Internet] to be an effective, rational and scalable alternative." - CEO, Firm C.

For the companies using personal selling personal direct marketing was also important means for marketing. In addition to the sales channels listed in the literature, the interviewees mentioned new marketing and sales models, such as use of trusted recommenders or sales agents forwarding leads to the SaaS provider sales personnel. The high level of sales provisions and channel management costs were seen to prohibit use of external resellers. Typically the external resellers receive 10$50 \%$ of the first year revenue from the new customer, from the total value of the agreement or from the sales transaction.

Next set of rows presents the entry transaction sizes of the interviewed SaaS providers categorized based on the order of magnitude. Most of the revenue is realized soon after the sales while fees form a continuous cash-flow, which can increase based on additional users or training fees. Contract periods used include annual and three-year contracts charged typically in the beginning while continuous contracts are charged monthly.

The interviews included multiple themes related to customer lifetime value; customer potential evaluation, customer categorization based on the relationship and estimation of customer lifetime value. The interviews indicated that the approach created based on literature is insufficient for estimating customer lifetime value. Most of the firms used the number of potential customers as the main metrics in evaluating the potential. However,

"Unfortunately we cannot classify the customers to high-potential or nonpotential beforehand rather than after starting the discussion" - Sales Director, Firm B.

Customers were not classified in Firm A, while Firm B assigned points to the customers based on the market segment and target group and firm D focused on strategic customers included in a ranking list. Various metrics were used for estimating business and sales performance related to customer lifetime value. Firm A evaluated customers based on time spent and revenue. Firm $\mathrm{C}$ used multiple metrics: new sales per salesman, outbound calls, conversations, scheduled sales meetings, inbound customer contacts, and number of new licenses sold. Firm D did not bring up tools for estimating customer lifetime value or customer potential. Firm B defined a clear goal for the first year customer lifetime value:

"Customer acquisition cost should be less than customer relationship value of the first year. It would be a great ratio, if the customer would pay [us] during the first year half of what it costs us." - Sales Director, Firm B. 


\subsection{Updated Model}

Based on the empirical results, we found it useful to revise the model somewhat. The eight dimensions were clustered into four internally interconnected areas represented as the leaves of a four-leaf clover in Figure 2. We added the key performance indicators (KPI) to the four areas taking into account both short and long term success of the firm. These KPIs are presented next to the area outside the clover.

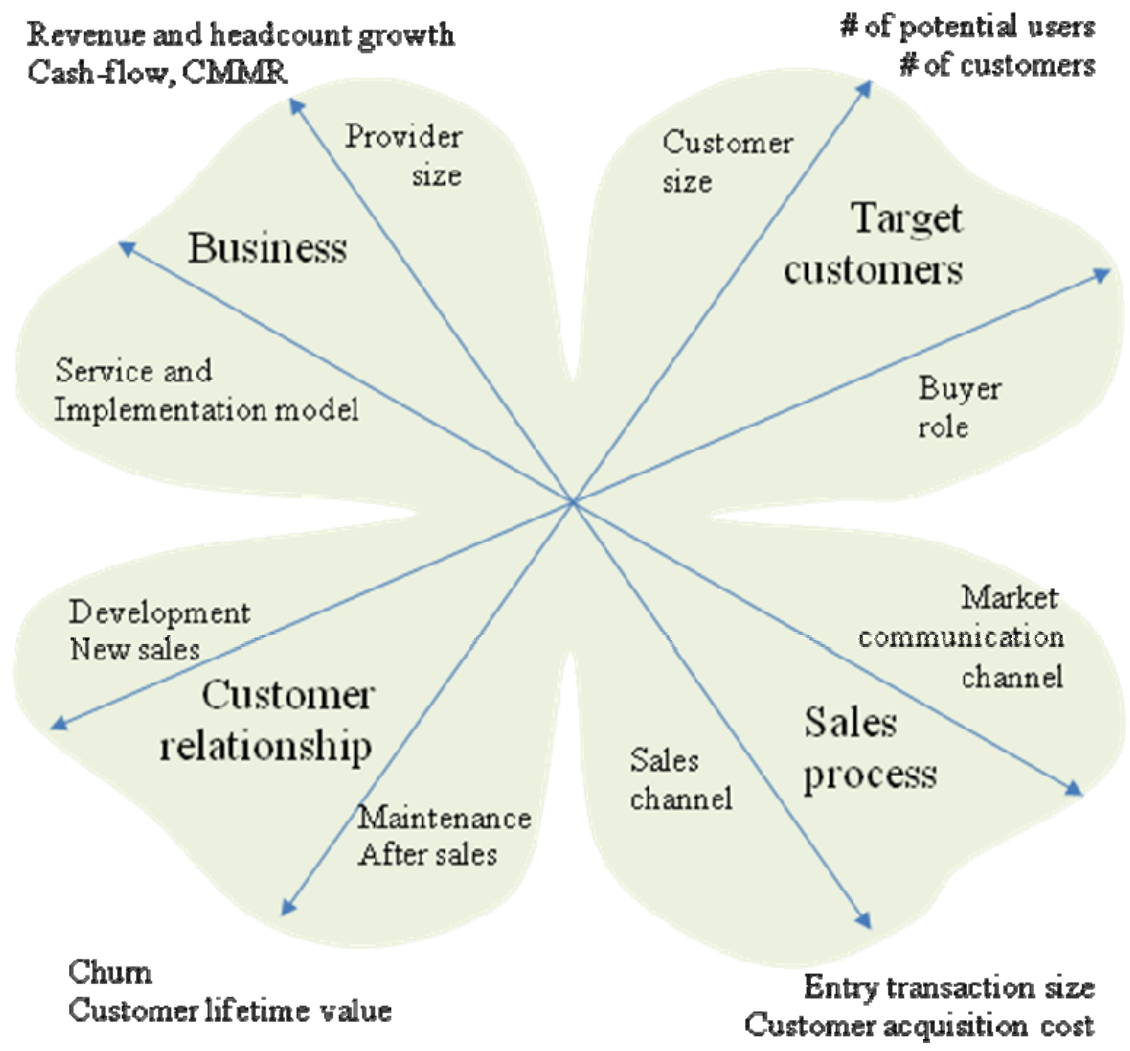

Fig. 2. The updated clover model for marketing and selling SaaS.

Out of the eight dimensions two were converted into KPIs, namely entry transaction size as a KPI of Sales Process and customer life-time value as a KPI of new area Customer Relationship. This new area contains two new dimensions related to development and maintenance of customer relationship. The scales of the old dimensions are mainly the same as in Figure 1 and due to simplicity they are not presented in Figure 2. The four areas containing the updated dimensions are as follows. 
- Business connects the dimensions Service and implementation model and Provider size. The scales of these dimensions are the same as in Figure 1. For example, Service and implementation model has values Self service, Development, Integration, Tailoring, as well as Training and Consulting. A typical SaaS firm in the empirical study was a small growth venture established especially for SaaS business. In this case the typical service and implementation model is self-service. Based on the empirical study the key performance indicators measuring best the success in business area include revenue and headcount growth, cashflow and committed monthly recurring revenue (CMRR) from current customer base.

- Target customers area connects together the two interconnected dimensions of Customer size and Buyer role. The scales of these dimensions are the same as in Figure 1. As observed in the interviews, in large customer organizations SaaS is purchased by business managers while in small organizations the top management does the decisions related to purchases. The number of potential users was found to be the critical indicator when defining target markets while the number of customers was key indicator of long-term success.

- Saless process includes the interconnected dimensions of Sales channel and Market communication channel. Unlike expected in the original model the common practice to use of Internet marketing did not imply use of Internet as a sales channel for business customers. Instead, use of personal marketing and personal selling were connected in the empirical study. For this reason the ordering of the values in Market and communication channel dimension needs to be updated accordingly positioning personal marketing along with personal direct sales in the outer ring representing high unit costs per customer. Based on the empirical study customer acquisition cost is the most important performance indicator of sales process, as also suggested in [38]. Interviews indicate also, that entry transaction size is directly related with cash-flow and should be treated as a performance indicator of the sales process rather than as a separate dimension of the model.

- Customer relationship area includes two new dimensions, Development referring to new sales and Maintenance referring to after sales. The maintenance of customer relationship is important to avoid churn and guarantee continuous cash-flow from the customer base. After sales support enables also development of the relationship and generation of new sales from the same customer organization. The two key performance indicators in SaaS customer relationship management are churn and customer lifetime value.

This revised model can be utilised in design of marketing and sales strategy for SaaS services as it brings together the key dimensions and their interconnections. The form of a four-leaf clover emphasizes the interconnectedness of the factors within and in between the areas. Especially, customer lifetime value cannot be discussed outside a wider context of a customer relationship. The model also provides key performance indicators for following progress in the main areas. 
From research perspective the customer relationship area of the updated model rising up from the empirical study has most development potential. This study has been focusing on the activities needed to make a customer to buy SaaS while the after sales activity gained less attention. Thus work is needed to deepen the understanding of the KPI - churn and customer lifetime value - in forthcoming research.

\section{Summary and Conclusions}

This paper presented a model for the main factors of marketing and selling SaaS constructed based on the literature. To our knowledge, such has not been presented in research literature prior to this paper. An explorative multi-case study was used for collecting empirical data and for validating the model. In general, the literature and the empirical observations were rather well in line although some changes were implemented into the updated model.

Based on the empirical results it seems that SaaS providers include small, medium size and large enterprises. The pure-player SaaS providers in our target group were small growth ventures, whose business model is based on providing SaaS services mainly for small enterprises based on customer self-service.

In general, the interviewed firms provided SaaS services for a wide range of firms from large corporations to small micro firms in the long tail. The dominant factor to determine the target group of customers was the number of potential users, which is directly related to the headcount of the customer organization.

The main sales channel was direct personal sales supported with Internet-based marketing communication. Internet as such was not much used as a sales channel, and advertising was not used in marketing communication.

The most important performance indicator for marketing and sales was customer acquisition cost. Customer lifetime value and churn were the key performance indicators for customer relationship management. There seems to be a need for better tools for estimating the customer lifetime value, which would be a fruitful target for further research. In addition, studying the impact of service platforms to marketing and selling SaaS would be a useful direction for further research.

In general, the studied SaaS providers resemble software product firms in having a high number of customers, small revenue per customer and high marketing and sales costs. They also share the problem of delay in cash flow between software development and revenue. The SaaS providers also share challenges of professional service providers in maintaining customer relationships and avoiding customer churn. Finding a marketing and sales approach matching these combined challenges originating from of both software product and professional services business will be critical to success of any SaaS firm in the near future.

Acknowledgments. This work was supported by TEKES (the Finnish Funding Agency for Technology and Innovation) as part of the Cloud Software Program of TIVIT (Finnish Strategic Centre for Science, Technology and Innovation in the field of ICT). 


\section{References}

1. Youseff, L., Butrico, M., Da Silva, D.: Toward a Unified Ontology of Cloud Computing. Grid Computing Environments Workshop, (2008) 1-10

2. Vaquero, L. M., Rodero-Merino, L., Caceres, J. et al.: A Break in the Clouds: Towards a Cloud Definition. ACM SIGCOMM Computer Communication Review, 39 (2008) 50-55

3. C. Pettey and H. Stevens. Gartner Says Worldwide SaaS Revenue to Grow 18 Percent in 2009, http://www.gartner.com/it/page.jsp?id=\%201223818

4. J. M. Kaplan. Software-as-a-Service Myths, http://www.businessweek.com/technology/ content/apr2006/tc20060417_996365.htm

5. S. Mallya. SaaS Sales Strategy, http://www.prudentcloud.com/saas/saas-sales-strategy25062009/

6. Jamcracker. When Selling SaaS, Don't Sell SaaS, http://www.jamcracker.com/WhenSelling-SaaS-Dont-Sell-SaaS-0

7. D. Domergue. PrudentCloudSaaS: Value Based Selling, http://www.prudentcloud.com/ saas/saas-value-based-selling-03082009/

8. L. Cone. The SaaS Model - Easy to Sell, http://it.toolbox.com/blogs/coneblog/the-saasmodel-easy-to-sell-18333

9. P. Radizeski. Top 3 Reasons its Hard to Sell SAAS, http://blog.tmenet.com/on-radsradar/2009/03/top-3-reasons-its-hard-to-sell-saas.html

10. Kotler, P., \& Keller, K. L.: Marketing management. Pearson/Prentice Hall, Upper Saddle River, NJ, USA (2009)

11. Jobber, D., \& Lancaster, G.: Selling and sales management. Prentice Hall/Financial Times, Harlow (2003)

12. Kotler, P.: Megamarketing. Harvard Business Review, 64 (1986) 117-124

13. Grönroos, C.: Keynote Paper from Marketing Mix to Relationship Marketing-Towards a Paradigm Shift in Marketing. Management decision, 35 (1997) 322-339

14. Tyrväinen, P.: Model for evolution of a vertical software industry. In: P. Tyrväinen and O. Mazhelis (eds.): Vertical Software Industry Evolution Analysis of Telecom Operator Software. Springer (2009) 25-33

15. Gupta, S., Hanssens, D., Hardie, B. et al.: Modeling Customer Lifetime Value. Journal of Service Research, 9 (2006) 139

16. Berger, P. D., \& Nasr, N. I.: Customer Lifetime Value: Marketing Models and Applications. Journal of Interactive Marketing, 12 (1998) 17-30

17. Venkatesan, R., \& Kumar, V.: A Customer Lifetime Value Framework for Customer Selection and Resource Allocation Strategy. J. Market., 68 (2004) 106-125

18. Hoch, D. J., Roeding, C., Lindner, S. K. et al.: Secrets of software success. Harvard Business School Press Boston (2000)

19. Tähtinen, J., \& Parvinen, P.: Ohjelmistojen markkinointi. In: E. Hyvönen (ed.). WSOY, Vantaa, Finland (2003) 41-76

20. Cusumano, M. A.: The business of software: What every manager, programmer, and entrepreneur must know to thrive and survive in good times and bad. Free Press (2004)

21. Ojala, A., \& Tyrväinen, P.: Business Models and Market Entry Mode Choice of Small Software Firms. Journal of International Entrepreneurship, 4 (2006) 69-81

22. Chong, F., \& Carraro, G.: Architecture Strategies for Catching the Long Tail. MSDN Library, Microsoft Corporation, (2006)

23. Rönkkö, M., Ylitalo, J., Peltonen, J., Koivisto, N., Mutanen, O., Autere, J., Valtakoski, A., Pentikäinen, P.: National Software Industry Survey 2009. Helsinki University of Technology, Espoo, (2009)

24. Moore, G. A.: Inside the tornado: Marketing strategies from silicon valley's cutting edge. HarperBusiness (1999) 
25. Zoltners, A. A., Sinha, P., Lorimer, S. E.: Match Your Sales Force Structure to Your Business Life Cycle. Harv. Bus. Rev., 84 (2006) 80

26. Rajala, R., Rossi, M., Tuunainen, V. K.: A Framework for Analyzing Software Business Models. (2003)

27. Choudhary, V.: Comparison of Software Quality Under Perpetual Licensing and Software as a Service. J. Manage. Inf. Syst., 24 (2007) 141-165

28. Sääksjärvi, M., Lassila, A., Nordström, H.: Evaluating the Software as a Service Business Model: From CPU Time-Sharing to Online Innovation Sharing. (2005) 177-186

29. Anonymous SoftwareMarketingAdvisor.comTips for SaaS Marketing, http://www.software-marketing-advisor.com/saas-marketing.html

30. D. Weobong. How to Sell SaaS, http://howtosellsaas.com/

31. Burrell, C.: SaaS New Engagement Approach in Europe by Fujitsu Services. Fujitsu Sci Tech J, 45 (2009) 275-282

32. Moore, G. A.: Living on the fault line, revised edition: Managing for shareholder value in any economy. HarperBusiness, New York, NY, USA (2002)

33. Anonymous THINKstrategiesCIO's Guide to Software-as-a-Service, $\mathrm{http}: / /$ thinkstrategies.icentera.com/portals/default.asp

34. T. Gardner. Financial Implications of the SaaS Business Model, http://www.sterlinghoffman.com/newsletter/articles/article339.html

35. Hirsijärvi, S., Remes, P., Sajavaara, P.: Tutki ja kirjoita. 13th edn. Tammi (2007)

36. Hirsjärvi, S., \& Hurme, H.: Tutkimushaastattelu: Teemahaastattelun teoria ja käytäntö. Yliopistopaino (2001)

37. Anonymous Cloud Software Program, http://www.cloudsoftwareprogram.org/

38. B. Deeter, D. Cowan, B. Goodman, et al. Bessemer Venture PartnersBessemer's Top 10 Laws for Being "SaaS-y", http://www.bvp.com/downloads/saas/BVPs_10_Laws_of_ Cloud_SaaS_Winter_2010_Release.pdf 